
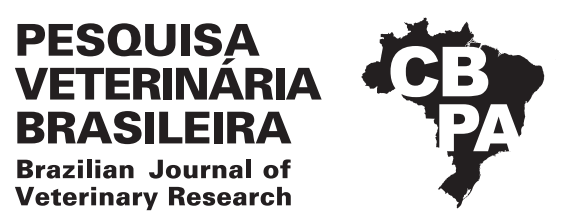

Pesq. Vet. Bras. 39(4):255-262, April 2019 DOI: 10.1590/1678-5150-PVB-5868

Original Article

ISSN 0100-736X (Print)

ISSN 1678-5150 (Online)

\title{
Diagnosis of canine leptospirosis: evaluation of two PCR assays in comparison with the microagglutination test ${ }^{1}$
}

\author{
Paula L. Martin²* (D), Nestor O. Stanchi², Bibiana F. Brihuega ${ }^{3}$, Estela Bonzo², \\ Lucía Galli ${ }^{4}$ and María S. Arauz ${ }^{2}$
}

\begin{abstract}
Martin P.L., Stanchi N.O., Brihuega B.F., Bonzo E., Galli L. \& Arauz M.S. 2019. Diagnosis of canine leptospirosis: evaluation of two PCR assays in comparison with the microagglutination test. Pesquisa Veterinária Brasileira 39(4):255-262. Servicio Central de Laboratorio, Hospital Escuela, Facultad de Ciencias Veterinarias, Universidad Nacional de La Plata, Av. 60 y 118, CC 296, La Plata, CP 1900, Buenos Aires, Argentina. E-mail: plmartin@fcv.unl.edu.ar

Canine leptospirosis is definitely diagnosed by demonstrating seroconversion in paired serum samples from the acute and convalescent period by the microagglutination test (MAT). However, the application of a polymerase chain reaction (PCR) assay can provide earlier confirmation of suspected cases. The objective of this study was to evaluate two PCR assays used in diagnosis of human leptospirosis (lipL32 real-time PCR and rrs conventional PCR) in cultured microorganisms and experimentally contaminated samples (whole blood, serum, urine), and investigate their applicability in clinical samples from dogs with presumptive diagnosis of leptospirosis by using the MAT as a reference. The analytical sensitivity of the lipL32 real-time PCR was 1 genome equivalent per reaction, whereas that for the rrs conventional PCR was 10 genome equivalents per reaction. Both assays amplified the pathogenic strains but were negative when evaluating the DNA of other microorganisms that may be present in clinical samples. The lipL32 real-time PCR detected 100 bacteria/mL in whole blood samples, 1000 bacteria/mL in serum samples and 10 bacteria/mL in urine samples, whereas the rrs conventional PCR detected 1000 bacteria/mL in whole blood and serum samples and 100 bacteria $/ \mathrm{mL}$ in urine samples. Seven out of the 51 samples from dogs with presumptive diagnosis of leptospirosis were considered as confirmed cases. The lipL32 real-time PCR detected positive results in six of the seven confirmed cases, whereas the rrs conventional PCR detected four. The PCR assays evaluated proved to be useful diagnostic tools in the confirmation of canine leptospirosis when used together with the MAT.
\end{abstract}

INDEX TERMS: Canine leptospirosis, PCR, microagglutination test, diagnosis, leptospirosis, dogs, bacterioses.

RESUMO.- [Diagnóstico de leptospirose canina: avaliação de dois ensaios de PCR em comparação com o teste de microaglutinação.] 0 diagnóstico definitivo da leptospirose canina é geralmente realizado demonstrando a seroconversão

\footnotetext{
${ }^{1}$ Received on September 17, 2018.

Accepted for publication on December 18, 2018.

${ }^{2}$ Servicio Central de Laboratorio, Hospital Escuela, Facultad de Ciencias Veterinarias, Universidad Nacional de La Plata (UNLP), Av. 60 y 118, CC 296, La Plata, CP 1900, Buenos Aires, Argentina. *Corresponding author: plmartin@fcv.unl.edu.ar

${ }^{3}$ Laboratorio de Leptospirosis, Instituto Nacional de Tecnología Agropecuaria (INTA), Nicolas Repetto y de los Reseros s/n, Hurlingham, CP 1686, Buenos Aires, Argentina.

${ }^{4}$ Consejo Nacional de Investigaciones Científicas y Técnicas (CONICET), Calle 81467 (B1904CMC), La Plata, Buenos Aires, Argentina.
}

em amostras do paciente no período agudo e de convalescença por serologia. No entanto, a aplicação de técnicas de PCR pode contribuir para a confirmação de casos suspeitos num período de tempo mais curto. 0 objetivo deste estudo foi avaliar dois ensaios de PCR publicados em humanos (PCR-lipL32 em tempo real e PCR-rrs convencional) em culturas puras e em amostras de sangue com anticoagulante, soro e urina experimentalmente contaminados. Posteriormente, investigamos a utilidade de ambos os ensaios de PCR em amostras clínicas de cães com suspeita de leptospirose tomando a técnica de microaglutinação (MAT) como referência. A sensibilidade analítica foi de 1 e 10 genoma equivalente por reação para PCR-lipL32 em tempo real e para PCR-rrs convencional, respectivamente. Ambos os ensaios amplificaram 
corretamente as 14 estirpes patogênicas, mas foram negativos para avaliar o ADN de outros microrganismos que poderiam estar presentes em amostras clinicas. Em nas amostras experimentalmente contaminadas PCR-LipL32 em tempo real detectou 100 bactérias/mL em sangue total, 1000 bactérias/mL em soro e 10 bactérias/mL em urina. Enquanto o PCR-rrs convencional detectou 1000 bactérias $/ \mathrm{mL}$ em sangue total e soro e 100 bactérias/mL na urina. Dos 51 cães suspeitos, sete foram considerados casos confirmados pela MAT. O PCR-lipL 32 em tempo real detectou seis dos sete casos confirmados, enquanto o PCR-rrs convencional foi positivo em quatro deles. As técnicas de PCR avaliadas provaram ser uma ferramenta de diagnóstico útil na confirmação de casos clínicos caninos quando utilizados em conjunto com a técnica MAT.

TERMOS DE INDEXAÇÃO: Leptospirose canina, PCR, teste de microaglutinação, caninos, diagnóstico, reação em cadeia da polimerase, bacterioses.

\section{INTRODUCTION}

Leptospirosis is a zoonotic disease caused by pathogenic species of the genus Leptospira, which are transmitted directly or indirectly from animals to humans. Canine leptospirosis has been associated mainly with the serovars Canicola and Icterohaemorrhagiae, but may also be associated with a wide range of serovars or genotypes (Rojas et al. 2010, Sykes et al. 2011, Loffler et al. 2014). The clinical presentation of acute canine leptospirosis can range from mild to severe, partly depending on the infecting serovar (Brihuega \& Martiarena 1996, Townsend et al. 2006, Kohn et al. 2010). The resolution of acute infection may lead to asymptomatic shedding. In addition, clinically normal dogs can be chronic carriers of infection, shedding Leptospira spp. to the environment (Harkin et al. 2003b). Early and accurate diagnosis of suspected cases in dogs is essential to alter the course of the disease. Therefore, validated diagnostic tools should be available to confirm a clinical suspicion (Fraune et al. 2013).

Definitive diagnosis of leptospirosis in dogs is currently achieved either by isolation of the bacterium from tissue or body fluids or by the use of the microagglutination test (MAT). The isolation of Leptospira spp. provides proof of infection, but culturing may take months and is not suitable to detect acute disease (Ahmed et al. 2012). On the other hand, the MAT requires the maintenance of a panel of live cultured microorganisms and the use of samples from the acute and convalescent period to confirm the diagnosis (Faine 1982). In contrast with these methods, polymerase chain reaction (PCR) assays have revolutionized the diagnosis of different diseases due to their sensitivity, making isolation and culture of the infecting microorganism not often necessary for a confirmatory result. Conventional or real-time PCR assays previously studied to detect Leptospira spp. target genes common to all Leptospira spp., including the $r r s$, gyrB, flaB and $\sec Y$ genes, or pathogen-specific genes, including the lipL32, ligA and ligB genes (Mérien et al. 1992, Levett et al. 2005, Palaniappan et al. 2005, Slack et al. 2006, Ahmed et al. 2009, 2012, Rojas et al. 2010, Monte et al. 2012, Koizumi et al. 2013, $\mathrm{Xu}$ et al. 2014). The advantage of a conventional PCR assay based on the detection of the rrs gene is its low cost, which allows using it in routine clinical diagnosis. In addition, the use of these primers increases the analytical sensitivity of the assay (Mérien et al. 1992, 2005) because the rrs gene has double copies on the chromosome of Leptospira species (Nascimento et al. 2004). On the other hand, the real-time PCR assay based on the detection of the lipL32 gene provides a specific method to detect pathogenic Leptospira and has several advantages compared to the conventional PCR assay, including a shorter turnaround time, increased specificity when $5^{\prime}$ nuclease assay probes are used, as well as a substantially less likelihood of cross-contamination. Both the lipL32 real-time PCR and the rrs conventional PCR assays have been demonstrated to be suitable tools to confirm clinical diagnosis of human leptospirosis (Levett et al. 2005, Stoddard et al. 2009, Villumsen et al. 2012). However, PCR assays standardized to be used in human clinical samples might not have the same performance when applied to dog samples (Schuller et al. 2015).

In dogs, these assays have been used to monitor renal colonization in experimental infection (Ahmed et al. 2012), to evaluate urinary shedding of Leptospira spp. in dogs (Harkin et al. 2003b, Rojas et al. 2010, Fink et al. 2015, Gentilini et al. 2015), and to detect Leptospira spp. in suspected patients (Harkin et al. 2003a, Fraune et al. 2013, Koizumi et al. 2013, Xu et al. 2014, Recavarren et al. 2015). Nevertheless, there is limited published information regarding the analytical sensitivity of conventional and real-time PCR assays in whole blood, serum and urine experimentally contaminated samples (Branger et al. 2005), the incorporation of internal amplification controls in the PCR assays (Fink et al. 2015, Recavarren et al. 2015) and the evaluation of different PCR assays using canine whole blood, serum and urine samples from suspected cases in comparison with the MAT (Xu et al. 2014, Fink et al. 2015). Moreover, the utility of the PCR assays in diagnosis of suspected dogs is still under debate (Harkin et al. 2003a, Fraune et al. 2013). Based on the above, the objectives of this study were to evaluate the lipL32 real-time PCR and the rrs conventional PCR with reference strains and experimentally contaminated samples and investigate their applicability in the diagnosis of leptospirosis in comparison with the MAT as a reference method, in whole blood, serum and urine samples from dogs with presumptive diagnosis of leptospirosis.

\section{MATERIALS AND METHODS}

Bacterial strains. Fifteen Leptospira strains (Table 1) and 16 other microorganisms (Pseudomonas aeruginosa, Klebsiella pneumoniae, Escherichia coli, Enterobacter aerogenes, Shigella dysenteriae, Proteus vulgaris, Proteus mirabilis, Morganella morgani, Staphylococcus aureus, S. pseudointermedius, S. epidermidis, Streptococcus canis, Ehrlichia canis, Borrelia burdogferi, Candida albicans and Hepatozoon canis) were included in this study. The Leptospira strains were obtained from the collection of the Instituto Nacional de Tecnología Agropecuaria de Castelar (Argentina), and maintained in leptospire-specific medium (Fletcher Medium Base, BD Difco, France) at $28^{\circ} \mathrm{C}$. Subcultures in leptospire-specific Ellinghausen-McCullough-Johnson-Harris (EMJH) medium (Leptospira Medium Base EMJH, BD Difco, France) were incubated at $28^{\circ} \mathrm{C}$ for 7 days before DNA extraction. The genomic DNA from the other microorganisms tested was gifted by colleagues from the Instituto de Zoonosis Luis Pasteur (Buenos Aires, Argentina), Instituto Malbrán (Buenos Aires, Argentina), and Laboratorio de Microbiología of the Facultad de Ciencias Veterinarias of the Universidad Nacional de La 
Plata (La Plata, Argentina). The non-Leptospira strains included in this study can be present in clinical samples (whole blood, serum and urine) and may cause unexpected cross-reactivity (nonspecific amplification). They were selected based on previous studies (Rojas et al. 2010, Gentilini et al. 2015).

DNA extraction. The DNA from Leptospira strains was extracted using a QIAamp DNA minikit (QIAGEN, Germany) according to the manufacturer's instructions. DNA concentration was determined by NanoVue Plus Spectrophotometer (GE Healthcare, USA). The number of Genomic Equivalents (GE), assuming one genome copy per Leptospira, was estimated based on a genomic size of $4.659 \mathrm{Mb}$ (Ren et al. 2003, Nascimento et al. 2004, Miotto et al. 2017).

lipL32 real-time PCR assay. The lipL32 real-time PCR assay to detect pathogenic Leptospira was conducted according to the method described by Villumsen et al. (2012), with some modifications. The probe was labeled with 6-carboxy-fluorescein (FAM) at the $5^{\prime}$ end and Iowa Black FQ (IBFQ) at the $3^{\prime}$ end (Integrated DNA Technologies, USA). The probe incorporates a new internal ZEN quencher that allows producing double-quenched probes with less background and more signal. The final volume of the assay was $25 \mu \mathrm{L}$ and consisted of $1 \mathrm{X}$ of KAPPA PROBE FAST qPCR Master Mix (2X) ABI Prism (KAPA Biosystems, MA, USA) 900nM of each primer (lipL32Fw and lipL32Rv), $250 \mathrm{nM}$ of probe and $5 \mu \mathrm{L}$ of template DNA. The sequences of these primers and probe are shown in Table 2. The following conditions were used for amplification: $95^{\circ} \mathrm{C}$ for 3 minutes, 40 cycles at $95^{\circ} \mathrm{C}$ for 15 seconds, $60^{\circ} \mathrm{C}$ for 1 minute.

Table 1. Leptospira strains used in this study

\begin{tabular}{lccc}
\hline \multicolumn{1}{c}{ Species } & Serogroup & Serovar & Strain \\
\hline \multirow{4}{*}{ P. interrogans } & Canicola & Canicola & Hond Utrecht IV \\
& Icterohaemorrhagiae & Copenhageni & M20 \\
& Pomona & Pomona & Pomona \\
& Pyrogenes & Pyrogenes & Salinem \\
& Pomona & Pujato & Pujato \\
& Sejroe & Hardjo & Hardjoprajitno \\
L. borgpetersenii & Sejroe & Wolffi & 3705 \\
L. borgpetersenii & Sejroe & Sejroe & M84 \\
L. noguchii & Ballum & Castellonis & Castellon 3 \\
L. weilii & Tarassovi & Tarassovi & Perepelitsin \\
L. kirschneri & Pomona & Proechimys & $1161 \mathrm{U}$ \\
\hline
\end{tabular}
Non-pathogenic

$\begin{array}{lccc}\text { L. } \text { meyeri } & \text { Ranarum } & \text { Ranarum } & \text { ICF } \\ \text { L. biflexa } & \text { Semaranga } & \text { Patoc } & \text { Patoc I }\end{array}$

The lipL32 real-time PCR assay was performed in a StepOne Plus Real-Time PCR System (Applied Biosystems, USA) and included a TaqMan Exogenous Internal Positive Control (Applied Biosystems, USA) to assess inhibition or suboptimal reaction conditions. The Internal Positive Control (IPC) included in this study was a heterologous target that included the primers and IPC-probe labeled with VIC ${ }^{\circledR}$ at the $5^{\prime}$ end and TAMRA ${ }^{\mathrm{TM}}$ Quencher at the $3^{\prime}$ end. Ultra-pure water and DNA from Leptospira interrogans serovar Canicola were used as negative and positive controls, respectively. Moreover, a DNA negative extraction control was included.

rrs conventional PCR assay. The rrs conventional PCR assay to detect Leptospira spp. was genus-specific and targeted to the rrs gene of Leptospira spp. We used a protocol published previously by Mérien et al. (1992), with minor modifications. The reaction mixture was prepared in a volume of $25 \mu \mathrm{L}$, containing $200 \mu \mathrm{M}$ of each deoxynucleotide triphosphate, $2 \mathrm{mM} \mathrm{MgCl}_{2}, 1 \mu \mathrm{M}$ of each primer (A and B), 1U Taq DNA Polymerase (Productos Bio-Lógicos, Argentina), and $5 \mu \mathrm{L}$ of template DNA. The sequences of these primers are shown in Table 2. Ultra-pure water and DNA from L. interrogans serovar Canicola were used as negative and positive controls, respectively. Moreover, a DNA negative extraction control was included. The rrs conventional PCR assay was performed in a Bio-Rad MyCycler Thermal Cycler PCR (Bio-Rad, CA, USA) with an initial denaturation at $94^{\circ} \mathrm{C}$ for 5 minutes, followed by 30 cycles of denaturation at $94^{\circ} \mathrm{C}$ for 30 seconds, annealing at $63^{\circ} \mathrm{C}$ for 60 seconds, extension at $72^{\circ} \mathrm{C}$ for 60 seconds, and final extension at $72^{\circ} \mathrm{C}$ for 10 minutes. The amplified products were electrophoresed on a $2 \%$ agarose gel in Tris-Borate-EDTA buffer $1 \times(89 \mathrm{mM}$ Tris, $89 \mathrm{mM}$ of boric acid, $2 \mathrm{mM}$ EDTA, pH 8.3) containing $1 \mu \mathrm{g} / \mathrm{mL}$ of ethidium bromide for 60 minutes at $90 \mathrm{~V}$. The bands were visualized under ultraviolet light $(296 \mathrm{~nm})$ and recorded using a Doc-It LS Image Acquisition and Analysis Software (UVP, Upland, CA, USA).

Evaluation of PCR assays with DNA samples of the reference Leptospira strains. To assess the analytical specificity of both PCR assays, DNA samples of the reference Leptospira strains (Table 1) as well as of the 16 other clinical important microorganisms were subjected to both PCR assays. To investigate the analytical sensitivity of both PCR assays, the DNA from L. interrogans Canicola Hond Utrecht IV and Copenhageni M20 was standardized to an initial concentration of $1 \times 10^{6} \mathrm{GE} /$ reaction, to perform serial 10 -fold dilutions in a DNA buffer consisting of Tris-EDTA buffer $(10 \mathrm{mM}$ Tris pH 8.0, $1 \mathrm{mM}$ EDTA) until reaching $1 \times 10^{\circ} \mathrm{GE} /$ reaction. All PCRs were run in triplicate. For lipL32 PCR real-time, the dynamic range, $\mathrm{R}^{2}$ coefficient and amplification efficiency for each strain were determined from the standard curve.

Evaluation of PCR assays in spiked whole blood, serum and urine samples. To evaluate the sensitivity of both PCR assays in biological samples, whole blood, serum and urine samples were spiked with the L. interrogans serovar Canicola strain Hond Utrech IV and subjected to amplification. The concentration of Leptospira spp.

Table 2. Primers and probe used in this study

\begin{tabular}{|c|c|c|}
\hline $\begin{array}{l}\text { Primers } \\
\text { or probe }\end{array}$ & Sequence $\left(5^{\prime} 3^{\prime}\right)$ & Reference \\
\hline lipL32Fw & AGAGGTCTTTACAGAATTTCTTTCACTACCT & Villumsen et al. 2012 \\
\hline lipL32Rv & TGGGAAAAGCAGACCAACAGA & \\
\hline Primer A & GGCGGCGCGTCTITAAACATG & Mérien et al. 1992 \\
\hline Primer B & TTCCCСCCATTGAGCAAGATT & \\
\hline
\end{tabular}


was determined using a Petroff-Hausser Counting Chamber (Hausser Scientific, USA). Counting was performed in duplicate in two separate aliquots and averaged.

The blood and urine samples used for the spiking experiments were acquired from healthy dogs. Blood was collected in K3 EDTA tubes and plastic serum tubes, whereas urine was collected in sterile urine collection cups. To confirm that the donor was not serologically positive for leptospirosis, MAT was performed following standard procedures (OIE 2008).

The appropriate amount of Leptospira spp. was spiked in whole blood, serum and urine samples so that the final concentration was $1 \times 10^{6}$ Leptospira spp./mL. Blood in serum tubes was spiked before clotting and then centrifuged. After spiking the whole blood, serum and urine samples, serial 10 -fold dilutions of $1 \times 10^{6}$ down to $1 \times 10^{\circ} / \mathrm{mL}$ were made. The DNA from each dilution (whole blood, serum and urine samples) was extracted using a High Pure PCR Template Preparation Kit (Roche Diagnostics, Germany) according to the manufacturer's instructions. The eluted DNA was kept at $-20^{\circ} \mathrm{C}$ until PCR assays. All PCRs were run in triplicate. For lipL32 PCR real-time, the dynamic range, $\mathrm{R}^{2}$ coefficient and amplification efficiency for each spiked sample were determined from the standard curve.

Application of both PCR assays and the MAT in clinical samples. This study included blood, serum and urine samples from 51 dogs with presumptive diagnosis of leptospirosis from the cities of Berisso, Ensenada and La Plata (Argentina) collected from July 2015 to December 2016. All samples came from dog patients cared for at the Hospital Escuela, Facultad de Ciencias Veterinarias, Universidad Nacional de La Plata, Buenos Aires, Argentina, according to animal welfare programs and with the informed consent of owners. The samples were analyzed at the Servicio Central de Laboratorio, Facultad de Ciencias Veterinarias, Universidad Nacional de La Plata.

Blood, serum and urine samples were examined by both PCR assays and an aliquot of serum was examined by MAT. Blood was collected in K3 EDTA tubes and plastic serum tubes, whereas urine was collected in sterile urine collection cups. Hematological, biochemical and urine analyses were performed within 12 hours of collection. Subsequently, whole blood and serum samples were stored at $-20^{\circ} \mathrm{C}$ until DNA extraction. Urine samples were processed according to the protocol described previously by Lucchesi et al. (2004) and kept at $-20^{\circ} \mathrm{C}$ until DNA extraction. DNA was extracted from aliquots using a High Pure PCR Template Preparation Kit (Roche Diagnostics, Germany) according to the manufacturer's instructions. The eluted DNA was kept at $-20^{\circ} \mathrm{C}$ before the PCR assays. All PCRs were run in triplicate. Samples with two or more positive reactions were scored as PCR positive.

The MAT was performed according to the standard method (OIE 2008). Briefly, the antigens were a panel of six live Leptospira reference strains representing the serovars most frequently found in dogs of Argentina: Castellonis, Canicola, Grippotyphosa, Copenhageni, Pomona and Pyrogenes. The strains selected were grown in EMJH medium at $28^{\circ} \mathrm{C}$ and serum samples were screened initially at a dilution of $1: 100$. The samples with positive reactions were subsequently serially diluted to the final titer. The end point was determined by the presence of $\sim 50 \%$ free unagglutinated leptospires compared with the control suspension.

The following case definition was adopted: a) confirmed leptospirosis case: patients with epidemiological, clinical and laboratory findings compatible with leptospirosis, where seroconversion to MAT (increase of at least four times in the titer for a serovar) was demonstrated or a single positive sample for more than one serovar (coagglutination) with at least one titer greater than or equal to 1/800; with no history of receiving recent antileptospiral vaccine; b) non-leptospirosis case: patients with negative MAT in two samples collected at different stages of the disease or a single positive sample with a titer lower than 1/800 (Goldstein et al. 2006, Ghneim et al. 2007).

Statistical analysis. The concordance between each PCR assay and the MAT was determined by calculating kappa values with $95 \%$ confidence intervals. According to kappa values, the concordance between assays was classified as following: 0-0.20 indicated poor agreement, 0.21-0.40 indicated fair agreement, 0.41-0.60 indicated moderate agreement, 0.61-0.80 indicated strong agreement, and 0.81-1 indicated almost perfect agreement (Landis \& Koch 1977).

\section{RESULTS}

\section{Evaluation of PCR assays with reference strains}

The lipL32 real-time PCR amplified all the pathogenic Leptospira but did not amplify the DNA of the saprophytic L. meyeri serovar Ranarum and L. biflexa serovar Patoc. Conversely, the rrs conventional PCR amplified all the pathogenic Leptospira and the saprophytic L. meyeri serovar Ranarum and L. biflexa serovar Patoc. Neither the lipL32 real-time PCR nor the rrs conventional PCR was able to amplify the DNA of other microorganisms. The IPC added to the lipL32 real-time PCR assay was detected in all cases, confirming the absence of inhibitors in the PCR runs. The analytical sensitivity was 1 and $10 \mathrm{GE} /$ reaction for the lipL32 real-time PCR and the rrs conventional PCR respectively. Using the serial dilutions of DNA from Leptospira interrogans Canicola Utrecht IV and Copenhageni M20, the lipL32 real-time PCR assay showed similar values of dynamic range, $\mathrm{R}^{2}$ coefficient, and PCR efficiency (Table 3 and Fig.1).

\section{Evaluation of PCR assays in spiked whole blood, serum and urine samples}

The sensitivity of the lipL32 real-time PCR assay was 100 Leptospira spp./mL in whole blood samples, 1000 Leptospira spp./mL in serum samples, and

Table 3. Results of dynamic range, $\mathrm{R}^{2}$ coefficient and PCR efficiency obtained with the lipL32 real-time PCR assay from reference strains and spiked whole blood, serum and urine samples

\begin{tabular}{|c|c|c|c|}
\hline & Dynamic range & $\mathrm{R}^{2}$ coefficient & Efficiency (\%) \\
\hline \multicolumn{4}{|c|}{ Reference strains } \\
\hline L. interrogans Canicola Hond Utrecht IV & $1 \times 10^{6}-1 \times 10^{0}$ & 0.99 & 100.88 \\
\hline L. interrogans Copenhageni M20 & $1 \times 10^{6}-1 \times 10^{0}$ & 0.99 & 100 \\
\hline \multicolumn{4}{|c|}{ Spiked samples } \\
\hline Whole blood & $1 \times 10^{6}-1 \times 10^{2}$ & 0.992 & 99.07 \\
\hline Serum & $1 \times 10^{6}-1 \times 10^{3}$ & 0.99 & 93.07 \\
\hline Urine & $1 \times 10^{6}-1 \times 10^{1}$ & 0.999 & 112.5 \\
\hline
\end{tabular}



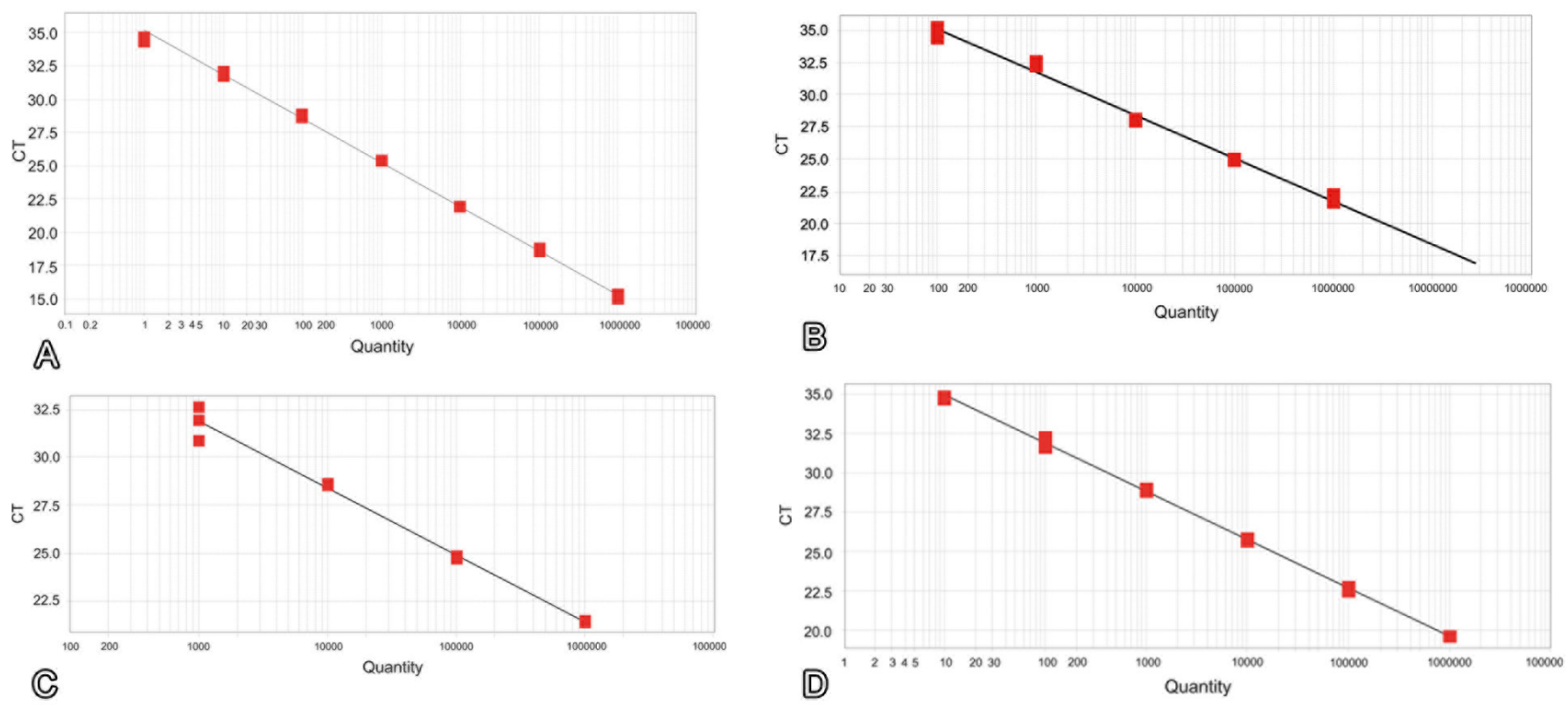

Fig.1. (A) Standard curve of the lipL32 real-time PCR assay using DNA of Leptospira interrogans Canicola Hond Utrecht IV. (B) Standard curve of the lipL32 real-time PCR assay using DNA of spiked whole blood samples. (C) Standard curve of the lipL32 real-time PCR assay using DNA of spiked serum samples. (D) Standard curve of the lipL32 real-time PCR assay using DNA of spiked urine samples.

10 Leptospira spp./mL in urine samples. Moreover, no PCR inhibition was identified in any of the reactions. The results of dynamic range, $\mathrm{R}^{2}$ coefficient and PCR efficiency obtained with the lipL32 real-time PCR assay from whole blood, serum and urine samples are shown in Table 3 and Figure 1. Regarding the $r r s$ conventional PCR, its sensitivity was 1000 Leptospira spp./mL in whole blood and serum samples, and 100 Leptospira spp./mL in urine samples.

\section{Application of both PCR assays and the MAT in clinical samples}

Seven out of the 51 serum samples tested by MAT were considered confirmed leptospirosis cases according to the definition adopted. The three most common serovars were Castellonis, Canicola and Copenhageni. The lipL32 real-time PCR was positive in six out of the seven confirmed cases, whereas the rrs conventional PCR was positive in four of them. The two urine samples positive by the lipl32 real-time PCR assay but negative by the rrs conventional PCR assay showed a threshold cycle $\left(\mathrm{C}_{\mathrm{t}}\right)$ value of 34.5 with the lipl32 real-time PCR assay.

Regarding the type of sample, all five patients positive by the lipL32 real-time PCR assay showed positive results in urine samples with $C_{t}$ values ranging from 15.9 to 35 , whereas only one patient showed positive results in whole blood and serum samples (with $C_{t}$ values of 29 and 33, respectively). Likewise, the $r r s$ conventional PCR assay was positive in the four urine samples of confirmed cases and only one patient was positive in whole blood sample. With regard to non-leptospirosis cases, 42 out of the 44 samples were also negative by both PCR assays, whereas 2 out of the 44 samples were positive in urine samples by both PCR assays. The IPC used in the lipL32 real-time PCR assay was positive in all samples tested, confirming the absence of inhibitors in the
PCR runs. In addition, the lipL32 real-time PCR assay showed a strong agreement (kappa $=0.76,95 \%$ IC $0.492-1.039$ ) when compared to the MAT. Conversely, the rrs conventional PCR assay showed a moderate agreement (kappa $=0.56,95 \%$ IC 0.286-0.833).

\section{DISCUSSION}

Canine leptospirosis is traditionally diagnosed using the microagglutination test (MAT). However, as mentioned, for a correct interpretation of the results, samples from the acute and convalescent periods are required. In addition, this test does not allow the confirmation of the disease in patients who died prior to blood sampling to evidence seroconversion. In human leptospirosis, several authors have demonstrated the usefulness of PCR as a diagnostic tool (Levett et al. 2005, Mérien et al. 2005, Ahmed et al. 2009, Stoddard et al. 2009, Boonsilp et al. 2011, Bourhy et al. 2011), while in veterinary medicine, particularly in canine leptospirosis, the validity of this technique to diagnose the disease has not been determined yet.

The sensitivity of the PCR assay obtained from cultured microorganisms has been previously determined in studies performed in human clinical samples (Mérien et al. 1992, Villumsen et al. 2012). In our study, both assays showed sensitivity values lower than those reported in these previous studies but similar to those described in other publications (Xu et al. 2014, Fink et al. 2015, Recavarren et al. 2015). On the other hand, all the pathogenic strains were correctly amplified, while a negative result was obtained when evaluating other genera of microorganisms that could be present in the clinical samples and cause nonspecific amplification.

Values of analytical sensitivity in experimentally contaminated whole blood, serum and urine samples differ from those obtained from cultured microorganisms. In our study, the lipL32 real-time PCR assay showed higher analytical sensitivity 
values in whole blood and urine samples than those reported by other authors in rat urine samples (Rojas et al. 2010) and similar to those reported in humans (Stoddard et al. 2009). Regarding serum samples, studies performed in humans (Stoddard et al. 2009, Bourhy et al. 2011) have shown that the analytical sensitivity and efficiency of the PCR are lower than those obtained in whole blood, coinciding with the results obtained in this study. The rrs conventional PCR was less sensitive in whole blood and urine samples than the lipL32 real-time PCR. However, the rrs conventional PCR showed values higher than those reported in human urine $\left(10^{4}\right.$ bacteria $/ \mathrm{mL}$ of urine) and similar to those obtained by other authors in canine urine after using a previous stage of immunomagnetic separation to increase sensitivity or a conventional PCR assay targeted hap1 gene (Lucchesi et al. 2004, Branger et al. 2005, Monte et al. 2012).

The incorporation of internal amplification controls in the PCR assays has contributed to verifying whether the efficiency of the assay has been affected during the amplification process (Gentilini et al. 2015, Recavarren et al. 2015). In this context, some authors have used primers targeted to canine endogenous gene fragments such as those encoding enzymes of cellular metabolism (glycerol-aldehyde-phosphate dehydrogenase or cytochrome) as the amplification control (Barker et al. 2010, Recavarren et al. 2015). This option has the advantage of evaluating the presence of inhibitors and the DNA extraction procedure. However, it is unsuitable for samples such as serum or urine because the presence of cells in this type of samples is usually poor (Gentilini et al. 2015). Therefore, a negative result for the amplification control may be erroneously analyzed as inhibition. In our study, incorporating an exogenous amplification control allowed avoiding the need to have somatic cells for proper amplification. With this approach, we obtained a positive result of the amplification control (mean $\mathrm{C}_{\mathrm{t}}$ value of 28) in all reactions, demonstrating the absence of inhibitors in the runs. In contrast, Recavarren et al. (2015), who used an endogenous amplification control, had to exclude 37 serum samples from their study because the amplification of the control was not adequate $\left(\mathrm{C}_{t}\right.$ value greater than 35$)$.

Several authors have evaluated the PCR assay in naturally infected dogs, but their results are discrepant (Harkin et al. 2003a, Fraune et al. 2013). Some of these authors (Harkin et al. 2003a) demonstrated the utility of a conventional PCR assay targeted to the gene encoding the $23 \mathrm{~S}$ ribosomal subunit from urine samples, obtaining sensitivity and specificity values of $100 \%$ and $88.3 \%$, respectively. However, in contrast, other researchers (Fraune et al. 2013) failed to detect any positive cases by means of a lipL32-based-nested-PCR assay performed from 15 whole blood samples and 10 urine samples from dogs diagnosed by MAT. Likewise, in another study, where the authors used a flaB-based-nested PCR assay, the sensitivity obtained was lower (62\%) than that obtained with the MAT in paired samples (90.9\%) (Koizumi et al. 2013). Although the sensitivity of these nested PCR assays is comparable to that of real-time PCR assays, other reasons could have influenced the results obtained by these authors. For example, the failure of the nested PCR in serologically confirmed cases can be attributed to the absence of the organisms in the sample secondary to the administration of antimicrobials or to the degradation of DNA during prolonged storage of the sample.
In our work, the lipL32 real-time PCR assay detected six out of the seven leptospirosis cases confirmed by MAT, while the rrs conventional PCR assay detected only four. Although the rrs conventional PCR assay showed a moderate agreement when compared to the MAT, it failed to detect two positive patients by the lipL32 real-time PCR assay. This finding could be attributed to the low bacterial concentration in the urine sample. Possibly, these patients positive by the lipL32 real-time PCR assay were shedding a low number of microorganisms that was below the limit of detection for the conventional PCR assay. Similar findings (patients positive by qPCR but negative by conventional PCR) have been reported by other authors (Fink et al. 2015). In addition, the lipL32 real-time PCR assay was positive in samples of two dogs before serological conversion was observed, reaffirming the usefulness of the lipL32 real-time PCR assay for the early confirmation of the disease, as described by other authors (Harkin et al. 2003a). Our lipL32 real-time PCR assay showed an adequate value of concordance with the MAT and allowed detecting a higher percentage of positive animals than that detected by other authors (Xu et al. 2014). Regarding confirmed cases, studies performed in dogs by Xu et al. (2014) and Fink et al. (2015) have shown a low percentage of positive cases, coinciding with our results. The cause of this finding is possibly due to the continued use of a vaccine for decades, with the consequent reduction of the clinical manifestation of the disease.

With respect to the type of samples used for the DNA search of Leptospira spp., in a previous study, Xu et al. (2014) evaluated 207 whole blood samples and 9 urine samples from 207 dogs by using three real-time PCR assays, and obtained three positive cases that showed amplification in urine samples and only one with the simultaneous presence of DNA in whole blood. However, in our study, the highest number of positive samples was obtained in urine samples by the lipL32 real-time PCR assay. Therefore, to increase the probability of a positive result, it would be advisable to jointly analyze whole blood and urine samples from the same patient (Schuller et al. 2015).

With the two PCR assays evaluated in the present study, two of the 44 patients classified as non-leptospirosis cases according to established criteria showed positive results in urine samples. Unfortunately, a second serum sample could not be obtained to evaluate the appearance of antibodies because the result of the MAT in both patients was non-reactive. However, these animals had epidemiological data, clinical signs and alterations in the parameters of blood biochemistry (increases in urea and creatinine values) compatible with leptospirosis. Our results agree with those described in other publications (Harkin et al. 2003a, Xu et al. 2014, Fink et al. 2015, Recavarren etal. 2015). Previous reports have also shown that serological results may be negative in the acute phase of the disease or inconsistent when the microorganisms are located in protected sites of the immune system (Birnbaum et al. 1998, Harkin \& Gartrell 1996). The possible explanations for the finding of seronegative animals in a single sample of the MAT but positive by PCR are multiple. Firstly, they could constitute false-positive results due to an unspecific amplification of DNA from the microorganisms present in urine (Fink et al. 2015). Secondly, animals infected with serovars that were not included in the panel of antigens tested would yield negative results. Finally, they could reflect a higher sensitivity of the PCR than 
the serology performed in the acute stage, especially in animals with exposure to risk factors and compatible clinical signs.

Previous studies have also shown negative results with the PCR assay in animals classified as confirmed cases of leptospirosis by serology (Fraune et al. 2013). The main cause of these findings is possibly the establishment of antimicrobial treatment before sample extraction and submission, the inadequate conservation of the sample, or the transient and/or intermittent shedding by dogs of pathogenic Leptospira in urine (Fink et al. 2015). In our study, the false-negative result using the real-time PCR assay corresponded to a dog patient that was initially treated in a private clinic, so we cannot rule out the previous administration of antibiotics.

\section{CONCLUSIONS}

The results of our study emphasize the importance of carrying out field studies to evaluate diagnostic assays because the tests with strains or experimentally contaminated samples may not be extrapolated to the situations encountered when attempting to diagnose leptospirosis.

PCR assays have been shown to be very useful for diagnosis when serological assays fail to detect antibodies or patients die before the convalescent serum sample can be obtained.

Although the MAT assay remains the most sensitive and standard technique for diagnosis, mainly when patients have been treated with antimicrobials, our results also highlight the utility of PCR assays as tools complementary to serology for the confirmation of leptospirosis cases in dogs.

\begin{abstract}
Acknowledgments.- We thank Dr. Cicuttin Gabriel and Dr. De Salvo Nazarena from the Instituto de Zoonosis Luis Pasteur for their assistance and Dr. Ahmed Ahmed and Dr. Goris Marga from KIT Biomedical Research (Leptospirosis research and diagnosis). We are also grateful to colleagues at Instituto de Genética Veterinaria (IGEVET) “Ingeniero Fernando Noel Dulout”, Laboratorio de Microbiología de los Alimentos, Servicio de Diagnóstico Bacteriológico y Antimicrobianos (SE.DI.ByA) and Hospital Escuela of the Facultad de Ciencias Veterinarias, Universidad Nacional de La Plata, Argentina.
\end{abstract}

Conflict of interest statement.- The authors have no competing interests.

\section{REFERENCES}

Ahmed A., Engelberts M.F., Boer K.R., Ahmed N. \& Hartskeerl R.A. 2009. Development and validation of a real-time PCR for detection of pathogenic leptospira species in clinical materials. PLoS One 4(9):e7093. <http:// dx.doi.org/10.1371/journal.pone.0007093><PMid:19763264>

Ahmed A., Klaasen H., van der Veen M., Van der Linden H., Goris M. \& Hartskeerl R.A. 2012. Evaluation of real-time pcr and culturing for the detection of leptospires in canine samples. Adv. Microbiol. 2:162-170. <http://dx.doi. org/10.4236/aim.2012.22021>

Barker E.N., Tasker S., Day M.J., Warman S.M., Woolley K., Birtles R., Georges K.C., Ezeokoli C.D., Newaj-Fyzul A., Campbell M.D., Sparagano O.A., Cleaveland S. \& Helps C.R. 2010. Development and use of real-time PCR to detect and quantify Mycoplasma haemocanis and "Candidatus Mycoplasma haematoparvum" in dogs. Vet. Microbiol. 140(1/2):167-170.<http://dx.doi. org/10.1016/j.vetmic.2009.07.006> <PMid:19646827>

Birnbaum N., Barr S.C., Center S.A., Schermerhorn T., Randolph J.F. \& Simpson K.W. 1998. Naturally acquired leptospirosis in 36 dogs: serological and clinicopathological features. J. Small Anim. Pract. 39(5):231-236. <http:// dx.doi.org/10.1111/j.1748-5827.1998.tb03640.x><PMid:9631358>

Boonsilp S., Thaipadungpanit J., Amornchai P., Wuthiekanun V., Chierakul W., Limmathurotsakul D., Day N.P. \& Peacock S.J. 2011. Molecular detection and speciation of pathogenic Leptospira spp. in blood from patients with culture-negative leptospirosis. BMC Infect. Dis. 11(1):338. <http://dx.doi. org/10.1186/1471-2334-11-338><PMid:22151687>

Bourhy P., Bremont S., Zinini F., Giry C. \& Picardeau M. 2011. Comparison of real-time PCR assays for detection of pathogenic Leptospira spp. in blood and identification of variations in target sequences. J. Clin. Microbiol. 49(6):21542160. <http://dx.doi.org/10.1128/JCM.02452-10> <PMid:21471336>

Branger C., Blanchard B., Fillonneau C., Suard I., Aviat F., Chevallier B. \& André-Fontaine G. 2005. Polymerase chain reaction assay specific for pathogenic Leptospira based on the gene hap1 encoding the hemolysisassociated protein-1. FEMS Microbiol. Lett. 243(2):437-445. <http://dx.doi. org/10.1016/j.femsle.2005.01.007><PMid:15686847>

Brihuega B. \& Martiarena B. 1996. Prevalencia de leptospirosis en insuficiencia renal en caninos. Revta Vet. Arg. 13:746-752.

Faine S. 1982. Guidelines for the control of Leptospirosis. World Health Organization, Geneva. 171p.

Fink J.M., Moore G.E., Landau R. \& Vemulapalli R. 2015. Evaluation of three $5^{\prime}$ exonuclease-based real-time polymerase chain reaction assays for detection of pathogenic Leptospira species in canine urine. J. Vet. Diagn. Invest. 27(2):159-166. <http://dx.doi.org/10.1177/1040638715571360> <PMid:25776541>

Fraune C.K., Schweighauser A. \& Francey T. 2013. Evaluation of the diagnostic value of serologic microagglutination testing and a polymerase chain reaction assay for diagnosis of acute leptospirosis in dogs in a referral center. J. Am. Vet. Med. Assoc. 242(10):1373-1380. <http://dx.doi.org/10.2460/ javma.242.10.1373><PMid:23634681>

Gentilini F., Zanoni R.G., Zambon E. \& Turba M.E. 2015. A comparison of the reliability of two gene targets in loop-mediated isothermal amplification assays for detecting leptospiral DNA in canine urine. J. Vet. Diagn. Invest. 29(1):100-104. <http://dx.doi.org/10.1177/1040638716672503> $<$ PMid:28074711>

Ghneim G.S., Viers J.H., Chomel B.B., Kass P.H., Descollonges D.A. \& Johnson M.L. 2007. Use of a case-control study and geographic information systems to determine environmental and demographic risk factors for canine leptospirosis. Vet. Res. 38(1):37-50. <http://dx.doi.org/10.1051/ vetres:2006043><PMid:17074294>

Goldstein R.E., Lin R.C., Langston C.E., Scrivani P.V., Erb H.N. \& Barr S.C. 2006. Influence of infecting serogroup on clinical features of leptospirosis in dogs. J. Vet. Intern. Med. 20(3):489-494.<http://dx.doi.org/10.1111/j.1939-1676.2006. tb02886. $\mathrm{x}><$ PMid:16734079>

Harkin K.R. \& Gartrell C.L. 1996. Canine leptospirosis in New Jersey and Michigan: 17 cases (1990-1995). J. Am. Anim. Hosp. Assoc. 32(6):495501.<http://dx.doi.org/10.5326/15473317-32-6-495><PMid:8906726>

Harkin K.R., Roshto Y.M. \& Sullivan J.T. 2003a. Clinical application of a polymerase chain reaction assay for diagnosis of leptospirosis in dogs. J. Am. Vet. Med. Assoc. 222(9):1224-1229. <http://dx.doi.org/10.2460/ javma.2003.222.1224> <PMid:12725309>

Harkin K.R., Roshto Y.M., Sullivan J.T., Purvis T.J. \& Chengappa M.M. 2003b. Comparison of polymerase chain reaction assay, bacteriologic culture, and serologic testing in assessment of prevalence of urinary shedding of leptospires in dogs. J. Am. Vet. Med. Assoc. 222(9):1230-1233. <http:// dx.doi.org/10.2460/javma.2003.222.1230 ><PMid:12725310>

Kohn B., Steinicke K., Arndt G., Gruber A.D., Guerra B., Jansen A., Kaser-Hotz B., Klopfleisch R., Lotz F., Luge E. \& Nöckler K. 2010. Pulmonary abnormalities in dogs with leptospirosis. J. Vet. Intern. Med. 24(6):1277-1282.<http:// dx.doi.org/10.1111/j.1939-1676.2010.0585.x><PMid:20738768>

Koizumi N., Muto M.M., Akachi S., Okano S., Yamamoto S., Horikawa K., Harada S., Funatsumaru S. \& Ohnishi M. 2013. Molecular and serological investigation of Leptospira and leptospirosis in dogs in Japan. J. Med. Microbiol. 62(Pt 4):630-636. <http://dx.doi.org/10.1099/jmm.0.050039$0><$ PMid:23264455> 
Landis J.R. \& Koch G.G. 1977. The measurement of observer agreement for categorical data. Biometrics 33(1):159-174. <http://dx.doi. org $/ 10.2307 / 2529310><$ PMid:843571>

Levett P.N., Morey R.E., Galloway R.L., Turner D.E., Steigerwalt A.G. \& Mayer L.W. 2005. Detection of pathogenic leptospires by real-time quantitative PCR. J. Med. Microbiol. 54(Pt 1):45-49. <http://dx.doi.org/10.1099/ jmm.0.45860-0 > <PMid:15591254>

Loffler S.G., Passaro D., Samartino L., Soncini A., Romero G. \& Brihuega B. 2014. Genotypes of Leptospira spp. strains isolated from dogs in Buenos Aires, Argentina. Revta Arg. Microbiol. 46(3):201-204. <http://dx.doi. org/10.1016/S0325-7541(14)70073-2><PMid:25444128>

Lucchesi P.M., Arroyo G.H., Etcheverría A.I., Parma A.E. \& Seijo A.C. 2004. Recommendations for the detection of Leptospira in urine by PCR. Recomendações para detecção de Leptospira em urina pela PCR. Revta Soc. Bras. Med. Trop. 37(2):131-134. <http://dx.doi.org/10.1590/S0037$86822004000200003>$

Mérien F., Amouriaux P., Perolat P., Baranton G. \& Saint Girons I. 1992. Polymerase chain reaction for detection of Leptospira spp. in clinical samples. J. Clin. Microbiol. 30(9):2219-2224. <PMid:1400983>

Mérien F., Portnoi D., Bourhy P., Charavay F., Berlioz-Arthaud A. \& Baranton G. 2005. A rapid and quantitative method for the detection of Leptospira species in human leptospirosis. FEMS Microbiol. Lett. 249(1):139-147. <http://dx.doi.org/10.1016/j.femsle.2005.06.011> <PMid:16006065>

Miotto B.A., da Hora A.S., Taniwaki S.A., Brandão P.E., Heinemann M.B. \& Hagiwara M.K. 2017. Development and validation of a modified TaqMan based real-time PCR assay targeting the lipl32 gene for detection of pathogenic Leptospira in canine urine samples. Braz. J. Microbiol. 49(3):584590. <http://dx.doi.org/10.1016/j.bjm.2017.09.004><PMid:29233483>

Monte L.G., Jorge S., Luiz J.P., Sinnott F., Seixas K.S., Aleixo J.A., Samartino L.E., Conceição F.R. \& Hartleben C.P. 2012. Diagnosis of canine leptospirosis using an immunomagnetic separation-PCR method. Braz. J. Microbiol. 43(2):602-605. <http://dx.doi.org/10.1590/S1517-83822012000200023> $<$ PMid:24031870>

Nascimento A.L., Ko A.I., Martins E.A., Monteiro-Vitorello C.B., Ho P.L., Haake D.A., Verjovski-Almeida S., Hartskeerl R.A., Marques M.V., Oliveira M.C., Menck C.F., Leite L.C., Carrer H., Coutinho L.L., Degrave W.M., Dellagostin O.A., El-Dorry H., Ferro E.S., Ferro M.I., Furlan L.R., Gamberini M., Giglioti E.A., Góes-Neto A., Goldman G.H., Goldman M.H., Harakava R., Jerônimo S.M., Junqueira-de-Azevedo I.L., Kimura E.T., Kuramae E.E., Lemos E.G., Lemos M.V., Marino C.L., Nunes L.R., de Oliveira R.C., Pereira G.G., Reis M.S., Schriefer A., Siqueira W.J., Sommer P., Tsai S.M., Simpson A.J., Ferro J.A., Camargo L.E., Kitajima J.P., Setubal J.C. \& Van Sluys M.A. 2004. Comparative genomics of two Leptospira interrogans serovars reveals novel insights into physiology and pathogenesis. J. Bacteriol. 186(7):2164-2172.<http:// dx.doi.org/10.1128/JB.186.7.2164-2172.2004><PMid:15028702>

OIE 2008. Leptospirosis, p.251-264. In: Ibid. (Ed.), Manual of Diagnostic Tests and Vaccines for Terrestrial Animals. 6th ed. World Organisation for Animal Health, Paris.

Palaniappan R.U., Chang Y.F., Chang C.F., Pan M.J., Yang C.W., Harpending P., McDonough S.P., Dubovi E., Divers T., Qu J. \& Roe B. 2005. Evaluation of lig-based conventional and real time PCR for the detection of pathogenic leptospires. Mol. Cell. Probes 19(2):111-117.<http://dx.doi.org/10.1016/j. mcp.2004.10.002><PMid:15680212>

Recavarren M., Quintana S., Rivero M., Ballesteros B. \& Scialfa E. 2015. Leptospira diagnosis in serum and urine of dogs by real time PCR. J. Vet. Sci. Med. Diagn. 4:2.

Ren S.X., Fu G., Jiang X.G., Zeng R., Miao Y.G., Xu H., Zhang Y.X., Xiong H., Lu G., Lu L.F., Jiang H.Q., Jia J., Tu Y.F., Jiang J.X., Gu W.Y., Zhang Y.Q., Cai Z., Sheng H.H., Yin H.F., Zhang Y., Zhu G.F., Wan M., Huang H.L., Qian Z., Wang S.Y., Ma W., Yao Z.J., Shen Y., Qiang B.Q., Xia Q.C., Guo X.K., Danchin A., Saint Girons I., Somerville R.L., Wen Y.M., Shi M.H., Chen Z., Xu J.G. \& Zhao G.P. 2003. Unique physiological and pathogenic features of Leptospira interrogans revealed by whole-genome sequencing. Nature 422(6934):888-893. <http://dx.doi. org/10.1038/nature01597><PMid:12712204>

Rojas P., Monahan A.M., Schuller S., Miller I.S., Markey B.K. \& Nally J.E. 2010. Detection and quantification of leptospires in urine of dogs: a maintenance host for the zoonotic disease leptospirosis. Eur. J. Clin. Microbiol. Infect. Dis. 29(10):1305-1309. <http://dx.doi.org/10.1007/s10096-010-09912><PMid:20559675>

Schuller S., Francey T., Hartmann K., Hugonnard M., Kohn B., Nally J.E. \& Sykes J. 2015. European consensus statement on leptospirosis in dogs and cats. J. Small Anim. Pract. 56(3):159-179. <http://dx.doi.org/10.1111/ jsap.12328> <PMid:25754092>

Slack A., Symonds M.L., Dohnt M.F. \& Smythe L.D. 2006. Identification of pathogenic Leptospira species by conventional or real-time PCR and sequencing of the DNA gyrase subunit B encoding gene. BMC Microbiol. 6(1):95. <http://dx.doi.org/10.1186/1471-2180-6-95><PMid:17067399>

Stoddard R.A., Gee J.E., Wilkins P.P., McCaustland K. \& Hoffmaster A.R. 2009. Detection of pathogenic Leptospira spp. through TaqMan polymerase chain reaction targeting the LipL32 gene. Diagn. Microbiol. Infect. Dis. 64(3):247-255. <http://dx.doi.org/10.1016/j.diagmicrobio.2009.03.014> <PMid:19395218>

Sykes J.E., Hartmann K., Lunn K.F., Moore G.E., Stoddard R.A. \& Goldstein R.E. 2011. 2010 ACVIM small animal consensus statement on leptospirosis: diagnosis, epidemiology, treatment, and prevention. J. Vet. Intern. Med. 25(1):1-13. <http://dx.doi.org/10.1111/j.1939-1676.2010.0654.x> $<$ PMid:21155890>

Townsend W.M., Stiles J. \& Krohne S.G. 2006. Leptospirosis and panuveitis in a dog. Vet. Ophthalmol. 9(3):169-173. <http://dx.doi. org/10.1111/j.1463-5224.2006.00464.x><PMid:16634930>

Villumsen S., Pedersen R., Borre M.B., Ahrens P., Jensen J.S. \& Krogfelt K.A. 2012. Novel TaqMan $\AA$ PCR for detection of Leptospira species in urine and blood: pit-falls of in silico validation. J. Microbiol. Methods 91(1):184-190. <http://dx.doi.org/10.1016/j.mimet.2012.06.009><PMid:22750039>

Xu C., Loftis A., Ahluwalia S.K., Gao D., Verma A., Wang C. \& Kaltenboeck B. 2014. Diagnosis of canine leptospirosis by a highly sensitive FRET-PCR targeting the lig genes. PLoS One 9(2):e89507.<http://dx.doi.org/10.1371/ journal.pone.0089507><PMid:24586833> 